\title{
ENVIRONMENTAL SECURITY AND SUSTAINABILITY: KITA-KYUSHU ECO- TOWN PROJECT AS A CASE STUDY
}

\author{
Syeda Naushin Parnini
}

\section{Introduction}

The concept of security has changed from traditional military thinking to a nonmilitary one by including environmental issues in the contemporary security agenda. Environmental degradation as a non-military threat has been advocated by Norman Myers, ${ }^{1}$ Richard Ullman ${ }^{2}$ and Michael Renner ${ }^{3}$ and Jessica Tuchman Mathews ${ }^{4}$. It can be considered as an addition to the momentum in the process of rethinking of the current concept of security. The version of environmental security, which informs this study, seeks to understand better the dynamics of relationship between environmental protection or management and social stability. This paper also aims to identify the freedom from threats to human health and social instability due to environmental degradation. It refers to responses to environmental threats and demands the relative public safety from environmental dangers caused by natural or human processes due to ignorance, accident, mismanagement originating within or across national borders. This paper focuses on the environmental security in which social systems interact with ecological systems in sustainable ways. It is to be noted that all individuals should have fair and reasonable access to environmental goods and mechanisms existing to address environmental crises. Environmental security is the cycling of natural resources to products and to wastes as well as to natural resources in ways that promote social stability, which can be observed in case of the Kita-Kyushu Eco-Town Project.

Asian countries have been facing environmental challenges ranging from pollution caused by industrialization process and rapid population growth, which again lead to increasing water, energy and food scarcity. To what extent these issues will shape the national security agenda of different countries are the main questions to be identified here. This paper argues that environmental difficulties are likely to be the primary cause of major security problems in the future which in turn might lead to both internal and external tensions and disputes. Moreover Southeast and East Asia suffer from many tensions that originate from ecological problems such as environmental degradation and pollution. That is the reason why Asian countries have to protect their environment by following environmental protection measures that are in practice elsewhere. Japan,

1 Norman Myers, Ultimate Security: The Environmental Basis of Political Stability, Island Press, October, 1996, pp. 129-140.

2 Richard Ullman, 'Redefining Security,' International Security, Vol. 8, No.129, 1983, pp.133.

3 Michael Renner, National Security: The Economic and Environmental Dimensions, World Watch Paper, Vol.89, Washington, D.C., 1989, pp.49-66.

4 Jessica Tuchman Mathews, Redefining Security', Foreign Affairs, Vol.68, No.2, 1989, pp. $162-177$. 
China and Korea should do so due to the fact that increasing environmental degradation and pollution as well as the threats resulting from rapid industrialization process might jeopardize peace and stability in Asia to a great extent. At the national level East Asian countries should follow a successful model such as the Kita-Kyushu Eco-Town project located in Western Japan for controlling their environmental pollution to tighten security at every sector. Eventually, the main question of this paper is how to apply the Kita-Kyushu environmental protection model, specifically its eco-town project, in other Asian big and polluted cities to protect the environment while simultaneously attaining sustainable development to strengthening market forces by reducing security threats emanating from environmental degradation.

\section{Some Theoretical Clarifications}

Because of globalization and increasing trans-national forces, the effect of the environment on security issues has become one of the most important issues in the present-day world. Environmental security is a comprehensive concept that encompasses many issues at the global scale while environmental problems contributes to political, social instability or conflicts sometimes at local, regional and international levels. ${ }^{5}$ Environmental security is still a fairly new concept in security and environmental literature. Its meaning and the policy prescriptions it engenders are contested. One major school of thought defines environmental security in terms of the potential conflict to arise from environmental degradation and resource scarcity. Most noted among this is the work done by Thomas Homer-Dixon ${ }^{6}$. He refers to environmental scarcity as a notion covering the relationships among environmental change, population growth and unequal social distribution of resources.

According to Marc Levy, in spite of impressive achievements, the research design devoted to studying the links between environmental change and violent conflict is in danger of obsolescence if it does not correct some quite serious methodological flaws. He finds previous research in environmental scarcity and conflict, particularly that by leading authority Thomas Homer-Dixon, "rather disappointing." He states that the findings of these studies are virtually identical to the conventional wisdom that prevailed before the research was carried out. ${ }^{7}$ The concept of environmental security underlying this paper is not to identify the relationship between environmental scarcity and violent conflicts; rather it seeks to understand better the dynamics of this relationship between environmental protection or management and social stability and national security and to explore the freedom from threats to human health and social instability due to environmental degradation.

There is a close link between national security and environmental issues. 'National security 'is of no use unless livable conditions exist in the nation. There is a growing understanding, among scientists and the general public, of the link between the human and natural system and the dependency role of the former on the later. Moreover, there is a growing recognition that the human system is threatening the stability of the natural system and, therefore, threatening human welfare. Additionally, the increasingly

5 Norman Myers, 'Environment and Security', Foreign Policy, No. 47, 1989, pp. 23-41

6 Thomas Homer-Dixon, 'Environmental Scarcities and Violent Conflict' Evidence from Cases', International Security, Vol. 19, No. 1, Summer 1994, pp. 5-40.

7 Marc Levy, 'Time for a Third Wave of Environment and Security Scholarship', The Woodrow Wilson Centre, Environmental Change and Security Project Report, Spring 1995, pp. 44-46. 
porous and inter-dependent nature of national borders makes this a national security issue. Haeuber ${ }^{8}$ also noted that policy makers and national security experts have yet to acknowledge the national security-environment link. He states that "development projects in developing countries, such as industries, dams, can reduce the amount of water and increase pollution in one area of the country. Population growth goes hand in hand with consumptions rates" and that both rates need to be curbed because of socio-economic and political change and upheaval within a nation. Migration, declining economic productivity and rivalry between religious or ethnic groups are just three of the examples he presented. In the final stage, socioeconomic and political changes weaken the state and surrounding states. Environmental pollution does not necessarily lead to war between nations; rather, it weakens the stability of a state or a region. These forces can result in unequal access to resources. This critical issue brings in the problem of population growth, poverty and inequality in Asian countries. When national security interests of these countries are threatened directly or indirectly by environmental factors, environmental security issues are born. We will discuss later how national security is threatened by environmental factors.

To determine whether an environmental factor constitutes a national security threat, it is first necessary to provide a working definition of a national security threat. Ullman $^{9}$ defines a national security threat as an action or sequence of events that: 1) threatens drastically and over a brief span of time to degrade the quality of life for the inhabitants of a state, or 2) threatens significantly to narrow the range of policy choices available to the government of a state or to private nongovernmental entities (persons, groups, corporations) within the state. Can environmental forces be considered a threat in Ullman's definition? They can, because his definition focuses on the condition of the security of the party threatened rather than the causes of the threat. The causes could be anything, including environmental. Security is couched in terms of the quality of life and the range of policy choices. Clearly, environmental factors affect quality of life by threatening human health. But what about potential threats, such as global climate change, that occur over a longer period than" a brief span of time" as indicated by Ullman. The current decisions regarding the environment and natural resources will affect the magnitude of their security risks over at least a comparable period of time, if not longer. Resource issues are likely to be the cause of much tension between states as well as within a state. The Ganges water disputes between India and Bangladesh and the fisheries dispute in the southern part of Bangladesh as two examples.

8 Richard, Haeuber, Sustainable Biosphere Initiative, A project of the Ecological Society of America, Washington, D.C., 2010, http:/ / www.iwa.org/Publications/Lectures/haeuber.htm.

9 Richardson Ullman, 'Redefining Security', International Security, Volume. 8, No.129, Summer, 1983, pp. 129-153. 
Figure 1 Environmental Security and Insecurity Nexus

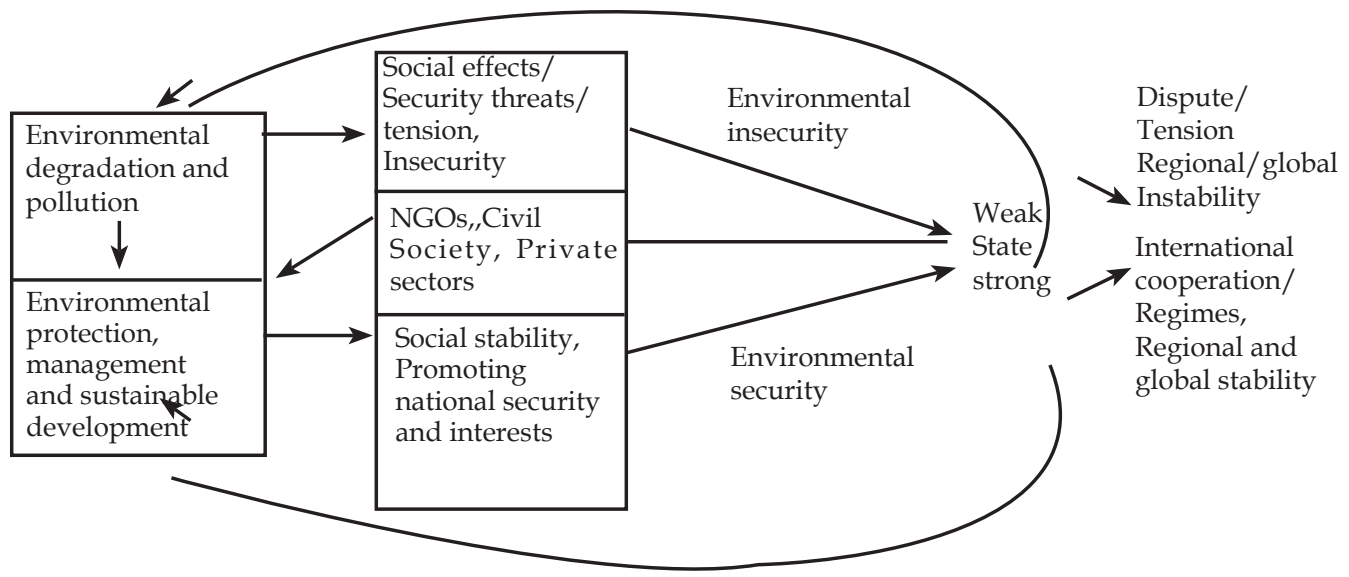

Global or regional problems such as climate change require international and regional cooperation under international regimes, while localized degradation and pollution are best addressed through a state's national environmental management authority and protection measures. There are no international governments, laws or courts that can enforce binding decisions on sovereign nations (with the partial exception of the European Union). But equally important actions taken by individual states or actors within states can have major international implications, such activities that cause trans-boundary pollution. While cooperation among nation-states has proven to be necessary to address many trans-boundary environmental issues, virtually all policies must be implemented at the national or local levels. ${ }^{10}$ States must be encouraged to reinvent their roles in environmental protection and management. Increasing public concern and growing scientific understanding of the complexity of environmental change have translated into expectations that states must find more effective ways of integrating environmental and developmental concerns.

In figure 1 we see how environmental pollution and degradation can lead to social conflict and instability that ultimately cause environmental insecurity and make a state weak. Such instability or insecurity can be escalated from a state to region or globe that might threaten national, regional and international security. It might have transboundary impacts too. A weak state ignores environmental pollution or degradation that leads to social tension and causes threats to security by enhancing environmental insecurity and vice-versa. However if environmental pollution is controlled by a government to promote sustainable development in cooperation with NGOs and private sectors, environmental security can be ensured to make a state stronger and enable it to go for regional and international cooperation on environment and vice versa.

Japan is a good example for success in integrating environment and developmental concerns to a great extent by taking measures to control environmental pollution in consequences of rapid industrial and economic growth. All these efforts ensure environmental security in Japan that advances its cooperation with regional mechanism

10 Richard Anthony Matthew, 'The Environment as a National Security Issue', Journal of Policy History, Vol.12, No. 1, 2000, pp.101-122. 
and international regime for environmental protection. The Kita-Kyushu Eco-Town project can be a model for Southeast and East Asia in this respect. This can be so because, in East Asia and elsewhere the link between environment and development is viewed as a competitive trade-off, where environmental considerations impose unnecessary costs and take much needed resources, especially from economic growth. The low priority assigned to environmental issues is, in turn, often reflected in the low budgets, limited staff, and limited authority of many national environmental agencies. Powerful domestic and international interests, especially private sector interests, influence environmental policy in Asia. When faced with a trade-off between policies that may help the environment but may hurt profitability of firms, government often further dilutes their limited environmental commitments. Such decisions hardly address environmental problems seriously and draw little attention towards its protection for sustainable development, and thus add to environmental insecurity for Asian countries. ${ }^{11}$

The concern in this paper is about the material well-being of individuals. There is no presumption that environmental threat is a traditional security issue which can be solved through military power. Therefore, Environmental security is the concept in which social (and thus political and economic) stability is controlled by the abundance and distribution of natural resources through protection of environmental pollution. In this paper environmental security thus consists of restoration, compliance, conservation, pollution prevention, environmental security technology at the national level together with regional or international activities and cooperation so as to control environmental pollution and ultimately ensure regional and global security. So, Asian countries need to give priority to environmental security issues in their national security agenda to promote their national interests and ensure sustainable development. Although environmental security issues can be trans-national in nature, the state remains the main actor to take initiative in order to meet the challenges of globalization to prop up national interests and security in cooperation with others on the basis of mutual gain. This will eventually ensure market forces by reducing tensions among states by creating level playing field for the countries at ASEAN regionally and at other international institutions. Thus, Asian countries can attain their goals to mitigate their environmental security problem following the model of Kita-Kyushu Eco-Town project.

\section{Environmental Security Problems in Asia}

Various types of environmental problems can contribute to national and regional instability in Asia. First and foremost, the increasing population growth in Asia may have serious environmental security implications. Population pressures already contribute to some social disorder and mass dislocations of the poor. Internally displaced persons, who may come across the land border, thereby becoming refugees i.e. Rohingya pose a long-term threat to the integrity of their own and other nations as well as to global stability. Two of the key factors that contribute to tension and insecurity throughout Asia are poverty and inequality. There are close and complex interconnections between people, the environment and livelihood opportunities in terms of access to natural resources, and vulnerabilities to environmental threats which are expressed in their overall impact on human survival, well-being and productivity. Insecurity often arises from conditions of inequality and impoverishment, such as is seen when political

11 Myers, Norman, 'Environment and Security`, Foreign Policy, No. 47, 198), pp., 23-41. 
and economic power relations affect society-nature interconnections as evidenced by 'resource capture' and 'ecological marginalization'.

In Asia, the problems of landlessness, impoverishment and resulting rural outmigration are compounded by environmental hazards as well as environmental degradation caused by economic development and rapid industrialization. Natural hazard- induced population displacement is endemic in many parts of Asia. It is estimated that natural hazards, on the average, displace more than a million people in Southeast and East Asia each year. ${ }^{12}$ In case of severe floods, tsunami or cyclones, the figures are much higher. On the other hand, different social conflict in different Asia has so far produced more than five million internally displaced people. Most of these people gravitate to the capital cities and other big cities. It is conservatively estimated that $40 \%$ of Asia's people live in squatters and slums.

The decline in food production, due to conversion of land for other uses, and agricultural land degradation are both major problems. Food scarcity can lead more migration from rural to urban areas, which can inter-group rivalries. Ecological process issues such as the greenhouse effect and the loss of bio-diversity are two of the major changes being studied today as they create a critical problem of coastal flooding. ${ }^{13}$ In an extreme scenario, an increase in sea level would lead to population displacement and change resource distribution, availability and scarcity. ${ }^{14}$ Changes in ecological processes, therefore, have enormous security implications. Environmental changes can lead to socio-political consequences that can cause intra-state or inter-state as well as regional conflicts in South and Southeast Asia. The security implications of environmental problems and changes are significant and vastly underplayed by the policy-makers. The measure of the difficulties in the future will be settled by the steps they take in the present. What is to be secured remains predominantly the survival of the state. ${ }^{15}$ Thus, environmental insecurity becomes synonymous with environmental threats to the state. ${ }^{16}$

Asian countries are aided by development policies and strategies funded by bilateral, multilateral aid agencies, and international and local NGO communities. Evidence shows that, the rush to intensified globalization can result in higher rates of displacement of peasant farmers from their livelihood bases that make them poor and unemployed. There is a rapid encroachment of vital common property resources and ecological reserves as well as coerced land polarization by new business interests. On the other hand, export- oriented production of agricultural commodities (e.g., seafood, cultured on arable lands, and vegetables for international markets) is giving quick rise to new entrepreneurs (producers and distributors) and middlemen. This creates inequality among people. People are often found to be resilient in a situation of environmental crisis. Communities develop stronger coping mechanisms to deal with adverse ecological

12 Report on Bangladesh and Climate Change, Bangladesh Bureau of Statistics, Statistical Unit of National Planning Ministry, Dhaka, 2001.

$13 \mathrm{Md}$. Koban Ali, 'Environmental Security of Bangladesh: In the case of Indo-Bangladesh Relations ', Pakistan Journal of Social Sciences, Vol.3, No7, 2005, pp. 902-908.

14 Keith Krause, 'Critical Theory and Security Studies,' Cooperation and Conflict, Vol.33, No.3, 1998, pp. 310. See also Astri Sukrke, 'Human Security and the Interests of States,' Security Dialogue Vol.30, No. 3 September 1999, pp. 102-104.

15 J. Barnett, The Meaning of Environmental Security: Ecological Politics and Policy in the New Security Era, Zed Books 2001, pp. 122.

16 L. Elliot, The Global Politics of the Environment, London: MacMillan, 1998, pp. 231. 
and economic conditions. But increasing resource depletion coupled with poverty is placing a heavy burden on their adaptive capabilities.

Within a coastal zone wherein agricultural lands are taken over (often by brute and violent force) for aqua culture (sea food production) aimed at an international market, and in which wage-labor jobs are severely limited in scope, duration and security, and often favor the most docile and vulnerable people. This context also has the additional dimension of long-lasting environmental destruction (salinity of agricultural land) to the acknowledgement of extremely short-term financial gains (export commodity for international restaurant chains) for small number of people. ${ }^{17}$

In an urban squatter settlement, which plays the role of a receiving centre of the rural displaced persons, conditions of people are worse. One of the primary concerns of the government of Asia should be the effect of environmental disaster that displaced population. All these have negative impacts on the social, political and environmental conditions in urban centers. Settlement of these displaced persons in urban centers exerts pressure on services and can create conflict with regular users. Usually they are deprived access to basic housing and health-care facilities. Overcrowding and accumulated wastes result in disease in the squatters. High density living, as in the capital cities and other big cities in Asia, means more wastes, more stoves, more vehicles and more air and water pollution. These trends have led to concerns about resentment and social unrest. The impact of environmental pollution on peoples' health takes a heavy toll on manufacturing service and agricultural productivity. Respiratory illnesses such as Acute Upper Respiratory Infections, acute bronchitis and chronic/ unspecified bronchitis have widely increased in polluted cities and are regarded as directly linked to exposure to air pollution. These diseases are affecting the quality of life in many areas. ${ }^{18}$ Water pollution in rivers near big cities of great impact on the livelihoods of fishermen as the fish can hardly survive in these polluted rivers. All these impacts put Asian countries into vulnerable situation, due to low productivity and low quality of life that hardly can alleviate poverty successfully.

Resource depletion and gradual deterioration of the environment induce migration not only within a country but also across its borders has caused disputes among South and Southeast Asian countries, adding to the trans-boundary water and marine resource sharing disputes among some countries. After commissioning of Farakka Barrage in 1975 over the Ganges River by India, heavy flooding during the rainy season and drought during the dry season in Bangladesh have become common phenomena every year. These are causing land erosion, low agricultural productivity, threat to the livelihood of farmers and fishermen and therefore forced migration from rural to urban areas within Bangladesh and across borders. These trends also cause food shortages and famines in the rural areas as well.

The security ramifications of greater social unrest should be of major concern for Asian countries. In an extreme situation, such as national water and food shortages, social unrest could generate widespread, coordinated action and political mobilization. While unrest presents the most obvious example of a security threat related to pollution, several other key concerns are worth noting. The cost of environmental destruction could, for example, begin to reverse the blistering rate of economic growth in Asia.

17 A.K.M. Abdus Sabur, 'Degradation of Environment as a Threat to the Security of Bangladesh; Sources and Challenges', BIISS Journal, Dhaka, 2001, Vol. 22, No.1, pp. 71-85.

18 A.K Azad and T. Kitada, 'Environmental Pollution and its control in Dhaka, Bangladesh: Implications of Urbanization, Journal of Global Environmental Engineering, 1998, Vol.4, pp.- 127-150. 
Estimates maintain that seven to ten percent annual growth is required to preserve social stability. Yet the costs of pollution are already taxing the economy between 8 and 12 percent of GDP per year. ${ }^{19}$ As environmental problems mount, this percentage will increase, in turn reducing annual growth.

With increasing populations and decreasing resources, Asian countries are facing growing environmental scarcity. There exist a number of environmental problems that can and have stimulated social or political instability, and thus pose threats to its national interests. Among these are degradation and erosion of farm land, ozone depletion, and pollution of water supplies, forestry depletion, and greenhouse-induced climate change patterns. These problems touch peoples' lives in social, economic, health, political and other respects. Therefore, we see that there is an essential connection between environmental degradation, population displacement, and poverty that national analysts must take into account. Severe environmental degradation and resource depletion may make economic recovery much more difficult for Asian countries from global economic recession of 2008, thereby prolonging dependence on aid and impeding its recovery from social or political problems and progress toward democracy and prosperity. Clearly, environmental security is at stake in many Asian countries. The following sections will discuss how to enhance the planning and management of national security interests through environmental protection by following the Kita-Kyushu Eco-Town Project as a model for Asian countries.

\section{Background of the Environmental Issues in Kita-Kyushu}

The city of Kita-Kyushu, a major city of Japan, situated in Fukouka Prefecture where it has flourished as one of the largest industrial centers of Japan. The modern industry of Japan began there in $1901 .{ }^{20}$ But the rapid development of this city also created some of the most serious cases of environmental or industrial pollution in the 1960s. Air borne particulars such as sulphur dioxide threatened the health and social security of its citizens. Especially in Dokai Bay near Kitakyushu, after years of contamination by industrial and domestic wastes, was so polluted that it was dubbed the 'Sea of Death' ${ }^{21}$ As a result no bacteria could live in Dokai Bay at that time. During this period of industrialization the sky rained down the highest level of polluted precipitation in Japan, earning it the name 'The Seven-Colored Smoke'.

\section{Process of Solving Problems and Its Outcome in Kita-Kyushu}

Kitakyushu City tried to combat the serious damage to its environment through the joint efforts of its citizens, the local government, involved universities and the industrial sectors. In 1971, the city set up a bureau to administer pollution-control measures, namely the present environmental bureau, even before the national government established the environment agency. The city has implemented one pollution control measure one after another, including the enactment of the Kitakyushu City Pollution Control Ordinance that establishes stricter criteria than the national standard, and various agreements on pollution control with major local industries. As a result of this

19 C. Bandon, Economic Valuation of Air and Water Pollution in Bangladesh, Workshop Discussion Draft, The World Bank, Washington D.C.1997.

20 See www.kitaq-ecotown.com/about/english/, retrieved 1 September 2011.

21 See www.kitakyu-cb.or.jp/eng/con03.html, retrieved 2 October 2011. 
process a citizen's movement for the protection of environment became evident, which drastically reduced pollution in the areas mentioned.

\section{Factors Contributing to Problem-Solving and Roles Played by Concerned Organizations in Kita-Kyushu}

The city has promoted a large-scale urban green development project under the Kitakyushu Plan. The city's policies on pollution control and environmental conservation have been supported by the private sector. The joint efforts greatly improved the environmental situation in the city. The Organization of Economic Cooperation and Development (OECD) presented the achievements of Kitakyushu to the World in a White Paper on the environment in 1985, reporting that Kitakyushu had transformed itself from a "City of Gray" to a "City of Green". Kitakyushu overcame serious levels of environmental pollution through the great efforts of its citizens, industries and universities and local government. During the process, they acquired a wide range of technologies and experience for pollution control and efficient production. ${ }^{22}$ Today, the city is actively working to promote Industrial Corporation in the field of environment by dispatching experts overseas and also by receiving foreign participants in local training programs as well as by holding international conferences. Working actively with developing nations, the city has been contributing to the preservation of environment at the global level.

\section{Pollution and International Environmental Cooperation in Kita-Kyushu}

The efforts of Kita-Kyushu to overcome pollution and to promote international environmental cooperation has won international recognition, including United Nation 500 award, presented by UNEP in 1990 and the UN's Local Government Honor awarded in 1992 at the UN Conference on Environment and Development held in Rio de Janeiro. Among Kitakyushu's many environmental cooperation projects, joint efforts with Dalian in the People's Republic of China have been especially promising. The cooperation between the two friendships cities began to grow after the pollution management seminar was held in Dalian in 1981.

In 1983 Kitakyushu proposed the Dalian Environmental Zone Demonstration Project, which strives to turn Dalian into a model environmental city. Currently Kitakyushu is working with Japan International Cooperation Agency (JICA) to this end. In addition to cooperating with Dalian city Kitakyushu has also formed an environmental cooperation network of 15 cities in 7 countries in both East and South East Asia. The network strives to promote sustainable development through inter-city environment and economic cooperation. In 1980 the Kitakyushu Inter City Environmental Association (KITA) was founded to provide technical support to developing countries for environmental and other projects. Through the cooperation of more than 200 local companies, academic and other local administrations, a total of 2370 people from 100 countries have participated in KITA`s training program by the invitation of JICA or the City of Kitakyushu (as of March 1998). Kitakyushu is determined to contribute to the creation of sustainable societies worldwide through close cooperation with International

22 See www.nkrc.co.jp/english/company_access.html, retrieved 4 October 2011. 
organizations such as the UN and the local government Initiative. ${ }^{23}$ Officials hope the recycling business also helps revive the troubled local economy.

\section{Eco-Town Plan and Present Activities in Kita-Kyushu:}

Thirty years ago, Kitakyushu, 970km southwest of Tokyo was a thriving town in Japan's so called rust belt. It was one of the country's biggest steel producers, the local Nippon Steel Plant employing 43000 people, which had once been 4000 . But along with countless slabs of steal it also produced thick brown smog that blanketed the city. The Kita-Kyushu Eco-Town project is based on a plan that has received national approval to convert and rebuild the industrial structure. This new industrial structure will be based on "mass production, mass consumption, mass abandonment" for a modern society in order to aim at "resource-recycling society" ${ }^{24}$ By reviewing the serious environmental problems that we have been facing now, we have to learn why a recycling society is inevitable. Different regulations have been passed for realizing an ideal society in Kita-Kyushu. It should be understood that the 3Rs (Reduce, Reuse and Recycle) followed by such Eco-town also means for all.

Eco-Technology has been produced for daily use and many products have been recycled within the Eco-Town Project. ${ }^{25}$ Familiar products such as cans, metals, plastics and paper are recycled here in this project. Some products made from recycled materials are as follows:
a. Biodegradable Plastics: Biodegradable plastic society
b. Eco-friendly Plastics: NEC Corporation
c. Eco-friendly Steel Products: Nippon : Nippon Steel Corporation
d. Eco-cement: Taiheiyo Cement Corporation
e. Recycling system for Concrete: Mitsubishi Materials Corporation
f. Recycling Aluminium Cans: Shinryo Aluminium Industry

Today Kitakyushu city's sky is clear. Eco town was built in 1997 on 2000 hectares of reclaimed area and consists of a boxy multi-storey building. The Kitakyushu Ecotown Plan, aims to create a 'Resource Circulating Economic Society' by planning a transformation of its industrial structure with an emphasis on environmental industries and under the goal of overcoming pollution. The objective of this Eco-Town Plan is to allow environmental industry to face the challenges of the twenty first century with a solid environmental management system supported by safe high-level technology. The main goal of this plan is to create a regional network for resource recycling by giving comprehensive support to each of the projects centred on the Hibikinada Area, in Wakamatsu Ward. The Kitakyushu Biotope Network Research Group (NPO KBN) has been found in July 2001. Members of the research group consist of university professors, company people, local government people, local citizens, students, etc. There are about 20 core members.

23 See website, www.kitakyushucci.or.jp/info/english/P_kita.html, retrieved 15 October 2011. 24 'The Boom of a Prosperous Eco-Society in the 21 ${ }^{\text {st }}$ Century', www.kitakyu-cb.or.jp/eng/con03. html - 18k - 30 May 2004, retrieved 15 August 2011.

25 `New Technologies to Promote a Prosperous Eco-society', www.jewww.jetrolosangeles.org/ Attachments/ Kitakyushu-Ecotown.pdf, retrieved 20 September 2011. 
At the end of June 2003 the Kitakyushu Biotope Network Research Group (KBN) has become a Non Profit Organization (NPO) Up to now, nearly all the activities of the NPO KBN have been taking place in the city of Kitakyushu and mainly in the area of the Wakamatsu ward. In former times, the Wakamatsu ward was an island, and still these days Wakamatsu ward is surrounded by water. It is surrounded by the Hibikinada Sea in the north, by the Dokai bay in the south and east, in the west by the Onga River, and in the south west by the Egawa River. Wakamatsu can be divided into 6 zones each with its own characteristic.

1) The old centre of the ward is situated in the east zone.

2) An old industrial area along the Dokai bay in the south.

3) A new residential area and academic zone, the so-called Kitakyushu Science and Research Park in the west.

4) In the north, the Wakamatsu seashore area where currently a new hub port is under construction and where the so-called Eco-Town, a new industrial area where mostly industries related to recycle techniques are located.

5) The zone geographically located in the centre of Wakamatsu has a rich abundant nature, and can be split up in a western and eastern part. The western part is mainly occupied by agricultural activities.

6) The eastern part has plenty of beautiful mountains with the Ishimine and Takato Mountain as the highest ones. ${ }^{26}$

Three of Kitakyushu's recently undertaken new urban developments, such as the new hub port, the Kitakyushu Science and Research Park, and the Eco-Town project, which are important for the economic development of the city are located in the Wakamatsu ward Industrial wastewater circulation recycling system considering the cost reduction has been introduced as a part of the emission reduction activity of the water.

Water purification plant, effective utilization of water resource, water saving process, reduction of the sewer aging and the state of the water reuse are significant efforts made by the Eco-Town plan. Hibikinada recycling area (Eco-town) is a good example of how Japanese high level of technological development help utilize resources effectively and eco-friendly. In every factory all workers are using technology to recycle old material. In a word, discarded materials are dissembled, hazard chemicals are removed, and then the appliances are broken down into little parts. The material is stored into glass, steal and plastic. The resin produced is used to create textiles and other goods. High quality parts from old office equipment such as fax machines are recovered as well. Research is in underway on the method of how to turn medical waste into fuel and other materials. The Eco town project has been working very well in Kita-Kyushu.

\section{Kita-Kyushu Eco-Town as a Model for Asia}

The Kita-Kyushu Eco-Town project can also be applied to other Asian countries. They are very useful to protect environmental degradation and draw eco-town framework for the polluted cities replicating the eco-town project of Kita-Kyushu. Since the KitaKyushu Eco-Town Project is contributing to prop up environmental security in Japan,

26 See http://en.wikipedia.org/wiki/wakamatsu_ward, retrieved 21 October 2011. 
the replication of such project can help prevent pollution to mitigate the transnational threat like environmental security as a whole. The Eco-town plan ensures environmental security that is freedom from threats to human health and social instability due to environmental degradation caused by rapid industrialization process. The plan suggests that other Asian countries should follow Japanese responses to environmental threats/ risks and relative public safety from environmental dangers caused by natural or human processes due to ignorance, accident, mismanagement or design and originating within or across national borders.

The condition of environmental security is one in which Japanese social systems interact with ecological systems in sustainable ways, all Japanese have fair and reasonable access to environmental goods, and mechanisms exist to address environmental crises. This promotes environmental security through the cycling of natural resources to products, to wastes, to natural resources in ways that promote social stability in KitaKyushu and other areas of Japan. Concerns about the insecurity individuals and groups (from small communities to humankind) experience in Bangladesh due to environmental change such as water scarcity, air and water pollution, global warming, and so on can be reduced by following the model of Kita-Kyushu Eco-Town Plan in Asian big polluted cities. Asian countries should learn lessons from the Japanese experience of Kita-Kyushu Eco-Town Project in ensuring its environmental security to promote national interests and stability. In detail the measures to be taken are:

\section{Initiative of Citizens}

The initiative of Japanese people is the determining factor for environmental protection and Eco-town activity. Without having the support and cooperation of citizens, the money and efforts paid by governments would not be very efficient. The Eco-Town Project shows that the movement for environmental protection in Kita-Kyushu in the 1960s was initiated by citizens who turned it to a successful scheme. For South and Southeast Asian countries, the first goal of local governments and NGOs should be directed to inducing the goal and motivating citizens to initiate environmental protection activities on their own and create eco-towns in their respective cities. Hence, next lesson for environmental protections arises and it is the education of citizens with regard to environmental issues.

\section{Education}

People would not initiate and support environmental issues without being aware of the seriousness of the problem. Therefore, the government and NGOs should take responsibility for giving education and knowledge to the people properly about environmental issues. Knowledge about the environment should be made available as part of formal education for children as has been done at the Kita-Kyushu environmental project.

\section{Cooperation of Citizens and other Institutions}

In many Asian cities environmental pollution is not yet framed as an environmental justice issue because economic and social elite dominated activism against environmental 
pollution for their personal gain. When it comes to environmental activism, this kind of top-down approach is not unusual. In general environmental measures have largely been focused on lobbying, consciousness-raising, and environmental education, rather than grass-root mobilization. Thus, it is learned from the experience of Kita-Kyushu city that the activities of citizens and private companies as well as local governments have to be coordinated instead of implementing only a top-down approach in this regard. Also it is very important that their activities are streamlined. Cooperation among people and streamlining of their activities are needed especially in big industrial cities aimed at the grass-root mobilization that must be directed towards achieving the same environmental goals.

\section{Developing Eco-friendly Technology}

Promoting the use of technology that will benefit the environment is essential for Asian polluted cities. Eco-Technology has been used to recycle not only wastes but also other products for daily use in the Kita-Kyushu Eco-Town Project. Familiar projects such as cans, metals, plastics and papers can also be recycled in Bangladesh as they are in the Kita-Kyushu project. Some products made from recycled materials in Kita-Kyushu such as Biodegradable Plastics, Eco-friendly Plastics, Eco-friendly Steel Products, Ecocement, Recycling system for Concrete, Recycling Aluminium Cans, can also be made possible and such techniques can be applied to Asian industries by using eco-technology if proper measure is taken in this regard.

\section{Making Reasonable Regulation}

Asian countries should take efforts, especially to enact various rules, laws and regulations congenial to United Nations Environmental Program (UNEP) and implement international conventions to overcome pollution and to promote international environmental cooperation including the implementation of the charter of UN Conference on Environment and Development held in Rio de Janeiro. It should also win international recognition by protecting its environment properly following the model of Kita-Kyushu. With the Earth Summit in Rio and the Kyoto Protocol in Japan, the 1990s have been a significant decade in reshaping conventional development thinking into sustainable development. This new trend guides us to clean up existing industries and develop new ones with minimum environmental impacts. In the process, development of recycling systems, waste exchange and industrial ecology will replace the linear industrial processes with a more circulatory structure.

\section{Providing Information}

Providing consistent, accessible information about the environment to citizens and institutions concerned. Every citizen of any Asian countries should be made aware of environmental problems through free flow of information. A small group formed by the conscious citizens has the potential to start a positive approach before anything can gain momentum and become recognizable. The government and renowned NGOs of can take effective steps in this regard. 


\section{Cleaning up and Getting People that have Experience in the Field}

Scientists are experimenting and making animal food from kitchen waste by trying to regulate chemical compounds for such animal food. At this point, Eco town recycles waste should not gain much profit. But officials in Kitakyushu are optimistic that the development of new environmental technologies will become a conversion of the former steal town development. In Asian countries initiatives should be taken to recycle kitchen wastes, garbage, medical and chemical wastes to be recycled into fuel and other useful materials as above in the Kita-Kyushu project and less-profitable recycling industries should be established first time either by government or by the private sectors that have the capability to establish such kind of industries. Moreover all industries in big cities should be operated in environmental-friendly way. Thereby it would be possible for Asian countries to establish eco-towns in different polluted industrial cities for sustainable development in the long run.

\section{Conclusion}

The field of environmental security studies is still largely an emerging one. There are ambiguities but this does not mean that we should not pay any attention to understanding environmental change and its relationship with national security and human survival. Emphasis also needs to shift away from focusing on conflict as an outcome of resource scarcity. The focus should be on the prevention of resource scarcity and pollution and increasing concerns about social disruptions and instability rather than the concerns about violent conflict as the principal sources of insecurity. This calls for the urgent need for mitigation against the root causes, and management of, environmental insecurities arising from threats such as pollution, degradation and climate change.

Environmental degradation, natural resource depletion, rapid population and industrial growth now pose threats to the prosperity of Asia and have security implications as mentioned above for both present and future national interests. The National Security Strategy needs to consider environmental issues as a component of national security planning. Public-private partnerships including NGOs and civil society partnerships should be formed through cooperation and joint initiatives to promote environmental security and sustainable economic growth, as well as to expand global environmental business opportunities. Thus, it is imperative that the key players, including governments, private firms, the international financial community, NGOs and civil society, work together more effectively to recognize the problems to find solutions, and also to see these through a successful implementation, monitoring and follow-up. This team approach will make the best use of dwindling resources by enhancing cooperation to reduce duplication of efforts in order to address existing gaps.

There exists a range of national policy measures and regulations, as mentioned above, to address environmental issues in different Asian countries. However, there is no integrating policy of most of the Asian governments to establish the requirement for solutions to environmental problems to be systematically developed, evaluated, prioritized and credited towards common security interests on the basis of mutual gain. The wise approach is to learn from the industrialized countries and take proactive measures in planning and managing the industrial sector. This paper summarizes the status quo of industrial development in Asia, by categorizing the existing industries 
and different kinds of environmental security problems in these countries. This paper has also analyzed the load of various pollutants, by reviewing the legal framework in the light of lessons learned from the Kita-Kyushu Eco-Town Project that will help reduce the impacts of pollution and global environmental change on security threats to Asia. Moreover, the policies as mentioned above should address the critical role of the private sector and civil society in every sector. Their activities need to be recognized by securing their participation in every sphere of a society. Without substantial changes in institutions and governance, economic policies, cross-cutting technological knowhow and behavior, the prospects for environmental protection remain bleak in Asia.

Thus, it is obvious that the Kita-Kyushu Environmental Protection projects for the creation of an eco-town with recycling products and resources can be considered as a model for the polluted cities in Asia for attaining sustainable development. The protection of the people in these cities from environmental security threats has become critically important to prevent conflicts or tensions within Asian countries and across the borders. Kita-Kyushu Eco-town plan ensures environmental security in a way which addresses the freedom from threats to human health and social instability due to environmental degradation. It shows appropriate responses of Kita-Kyushu town to environmental threats and the relative public safety-net from environmental dangers caused by natural or human processes due to ignorance, accident, mismanagement originating within or across national borders.

The basis of environmental security in Kita-Kyushu Eco-Town Project is the one in which Japanese social systems interact with ecological systems in sustainable ways; all citizens have fair and reasonable access to environmental goods and mechanisms. That is why, citizens of different countries in Asia, especially the people of the industrial cities, should become active participants like Kita-Kyushu citizens in protecting the environment and also in creating an eco-town for protecting themselves against the environmental threats. Of course, we cannot ignore the vital role of the central and local governments, the private sectors and civil society in this regard. Apart from national efforts that make a state stronger and more sustainable, regional or international cooperation is essential to solve trans-boundary environmental problems which can ultimately contribute to regional and global peace and stability.

Although most of the developing countries in Asia do not have ample resources or much financial capability like Kita-Kyushu in Japan, they have to combat environmental threats in their polluted cities by making full utilization of their small range of resources and also by supporting efficient efforts of the people concerned. These countries can also seek support from the Kita-Kyushu environmental project as this project has been giving financial support to developing countries. Emerging countries in Asia can send resource persons, who are experts in environmental issues, as participants to different environmental training programs and workshops, undergoing in Kita-Kyushu, to learn lessons pertaining to environmental protection by establishing eco-towns. In this way the Kita-Kyushu model can be a good example to Asian countries in order to save their polluted cities from disaster by recycling most of their resources for sustainable development. This will eventually strengthen market forces and industrialization process to a great extent by addressing environmental security and sustainability in most of the Asian countries and their citizens while promoting national and common interests in the era of globalization. 
Jurnal EAJIR Bab 3.indd 52 